\title{
Secret Routes and Blurring Borders: The New Apartment of Giuseppe Papè di Valdina (Palermo, 1714-1742)
}

\author{
Valeria Viola
}

By ascribing various names and functions to a significant number of different rooms, early modern treatises suggest that an increasing specialisation of domestic spaces was in progress in Italian residential architecture. ${ }^{1}$ Despite the manifold nuances often emerging from case studies, scholars have usually identified this period as showing the beginning of a rising quest for intimacy and privacy connected to a more defined division between anterooms open to visitors and more withdrawn backrooms, owners' and servants' areas, male and female spaces, and so on. ${ }^{2}$ However, other studies investigating the interactions between domestic spaces and the people experiencing them have argued that the spatial arrangement of aristocratic dwellings long remained adaptable to multiple uses and allowed continuous negotiations of roles and

1 This case study was first approached in my $\mathrm{PhD}$ thesis Architecture, Devotion, Family Life: Aristocratic Houses of Baroque Palermo (ca. 1650-1770), which was conducted at the Art History Dept. of the University of York and supervised by Prof. Helen Hills (PhD awarded in 2020). I sincerely thank the architect Giuseppe Barresi, who provided me with drawings and photographs that were essential to understand the internal structure of a building that is now inaccessible. The paper also benefitted from my participation in the Early Modern Privacy conference, Notions, Spaces, Implications, organised by the Danish National Research Foundation Centre for Privacy Studies in Copenhagen in April 2019. All translations from Italian are mine. By 'early modern treatises' I refer here to architectural treatises and etiquette manuals circulating in the Italian peninsula and in Sicily in the early modern period. In the same context, however, legal documents and notarial deeds provide us with a more complicated picture, thus allowing historians to overcome what Giulia Calvi defines as the 'distortion between representation and practices', see Calvi G., "Maddalena Nerli e Cosimo Tornabuoni: Comportamenti domestici ed affettivi (XVI-XVII secolo)", in Visceglia M.A. (ed.), Signori, patrizi, cavalieri nell'età moderna (Rome: 1992) 265.

2 For Southern Italy, see Luise F., "Gli spazi delle residenze aristocratiche tra intimità e esigenze rappresentative”, in Denunzio A.E. - Di Mauro L. - Muto G. - Schütze S. - Zezza A. (eds.), Dimore signorili a Napoli. Palazzo Zevallos e il mecenatismo aristocratico dal XVI al XX secolo (Naples: 2013) 95; Giuffrè M., "Palermo. La cultura dell'abitare fra tradizione e rinnovamento", in Simoncini G. (ed.), L'uso degli spazi privati nell'età dell'Illuminismo (Florence: 1995) $543-544$. 
spaces. ${ }^{3}$ The issue has also provoked interesting debates in relation to places other than the Italian peninsula. ${ }^{4}$

This paper contributes to the discussion by challenging the overwhelming attention paid to Central and Northern Italy, that is, by focusing on the renovation of the Palazzo Papè di Valdina in Palermo, which was carried out between 1714 and 1742. As an example of extremely complex connections between various dwellings, a monastery, a church, and the city, this case study offers the opportunity to explore the boundaries between different areas and spheres (private and public, personal and familial, female and male, secular and religious) and to investigate the issue of privacy in relation to the negotiation of these boundaries. ${ }^{5}$

Hailing from Antwerp, the Papè family began rising to prominence in Naples in 1535 with the military career of Giovanni Tomaso Papè, knight of Charles V (1500-1558). ${ }^{6}$ After a century, the family moved to Palermo, where they found

3 Maurer M.F., Gender, Space and Experience at the Renaissance Court:Performance and Practice at the Palazzo Te (Amsterdam: 2019) 43; Smith A. "Revisiting the Renaissance Household, in Theory and in Practice: Locating Wealthy Women in Sixteenth-Century Verona", in McIver K. (ed.), Wives, Widows, Mistresses, and Nuns in Early Modern Italy: Making the Invisible Visible through Art and Patronage (Farnham: 2011) 141-157.

4 In relation to early modern French abodes, Sara Galletti underlines the need of clarification when terms such as private and public are used, see Galletti S., "The Royal Gallery at the Time of Henry IV. Architecture and Ceremonial", in Nativel C. - Capodieci L. (eds.), Henri IV: Art et Pouvoir (Tours: 2016) 329; Juan Postigo Vidal argues for a temporary balance between versatility and specialisation of domestic space in seventeenth-century Zaragoza, see Vidal J.P., "El Espacio Domestico en Zaragoza en el siglo XVII: Versatilidad y Especialización", Historia Social 73 (2012) 22-23; Lena Cowen Orlin's research on domesticity argues that privacy was a secondary objective in designing houses in Tudor London, see Orlin L.C., Locating Privacy in Tudor London (New York: 2009) 9-10.

5 The paper investigates privacy in spatial and experiential terms, by exploring the distance that people could experience from spaces variably shared with others, both within and without the house. In this sense, the term privacy is associated with the Italian word riservatezza, which implies both withdrawal and confidentiality. However, the paper does not rely on individual perceptions of the space nor on personal memories of its use since no personal letter or diary has been traced.

6 Archivio di Stato di Palermo (hereafter: ASP), Papè, vol. 395, fol. 1. The document, which reports the services of the heads of the Papè family to the Crown of Spain, gives no other information regarding this ancestor except that on 20 October 1535 he was granted the privilege of becoming a royal soldier. 
suitable ground for their social ascent. ${ }^{7}$ Like many other aristocratic families, as soon as they were established in Palermo, they started negotiations for social and physical space to enhance their visibility. In society, the heads of the Papè household pursued political recognition through engagement with the administration of the viceroyalty. ${ }^{8}$ In 1624, Cristoforo Papè (1607-1666) bought the office of Protonotaro del Regno (Master Notary of the Kingdom) for 27 ,ooo scudi, and in 1643 asked for and obtained from the king the extension of it 'a due vite' ('to two lives'), namely to his son Ugo (1647-1701) and his grandson Giuseppe (ca. 1685-1742)..$^{9}$ The office long remained the most significant trait of the lineage, but the family also supported their position and wealth by collecting many rich fiefs around Palermo through profitable marriages into families of ancient nobility. ${ }^{10}$ Within the urban fabric, the Papè family settled in the highest part of the most central street, known as the Cassaro. The palace was a complex of pre-existing houses, which in 1651 passed into the hands of Cristoforo from his wife's assets. ${ }^{11}$ This block was part of the first settlement of Palermo (sixth-seventh centuries BC), not far from the cathedral, and flanked by two narrow alleys starting from the Cassaro and perpendicular to it [Fig. 18.1a-b]: to the east the alley today called via del Protonotaro and to the west the alley now known as vicolo del Lombardo.

The family negotiated its own spaces in the neighbourhood through architecture. For example, the renovation of the adjacent church dedicated to Saint Thomas of Canterbury became a way to forge alliances as Giuseppe chose a Jesuit architect, Agatino Daidone (1672-1724), from the nearby Collegio Massimo to direct the works. However, architecture also generated rivalries and disputes, especially because the search for space often entailed an ambition for a view. Joseph Connors argues that much of the residential architecture in Baroque Rome was shaped by adjustments aimed at visual prominence - in

Mugnòs Filadelfo, Teatro genologico delle famiglie nobili di Sicilia nobili, titolate, feudatarie, vol. 3 (Messina, Stamperia di Giacomo Mattei: 1670) 56. On the mobility of aristocracy towards and within Sicily, see Ligresti D., Sicilia aperta (secoli XVI-XVII): Mobilità di uomini e di idee (Palermo: 2006) 78-91.

8 At that time, Sicily passed from the Spanish Crown to the House of Savoy (1713-1720), to the Habsburgs of Austria (1720-1734), and to the Bourbons of Naples (from 1734). Palermo was the main ceremonial venue of the viceroy.

9 Salamone L., L'archivio privato gentilizio Papè di Valdina (Messina: 1999) 19-20. The role of Protonotaro included the organisation of ceremonials of the viceroy, the surveillance of the notaries of the kingdom, their designation, destination, and removal, and special offices inside the Sicilian Parliament and the Deputation of the Kingdom. Emanuele e Gaetani Francesco Maria, Della Sicilia nobile, vol. 1 (Palermo, Stamperia de' Santi Apostoli: 1754) $84-85$.

10 Salamone, L'archivio privato, 21, 37.

11 ASP, Papè, vol. 54, fol. not numbered. 

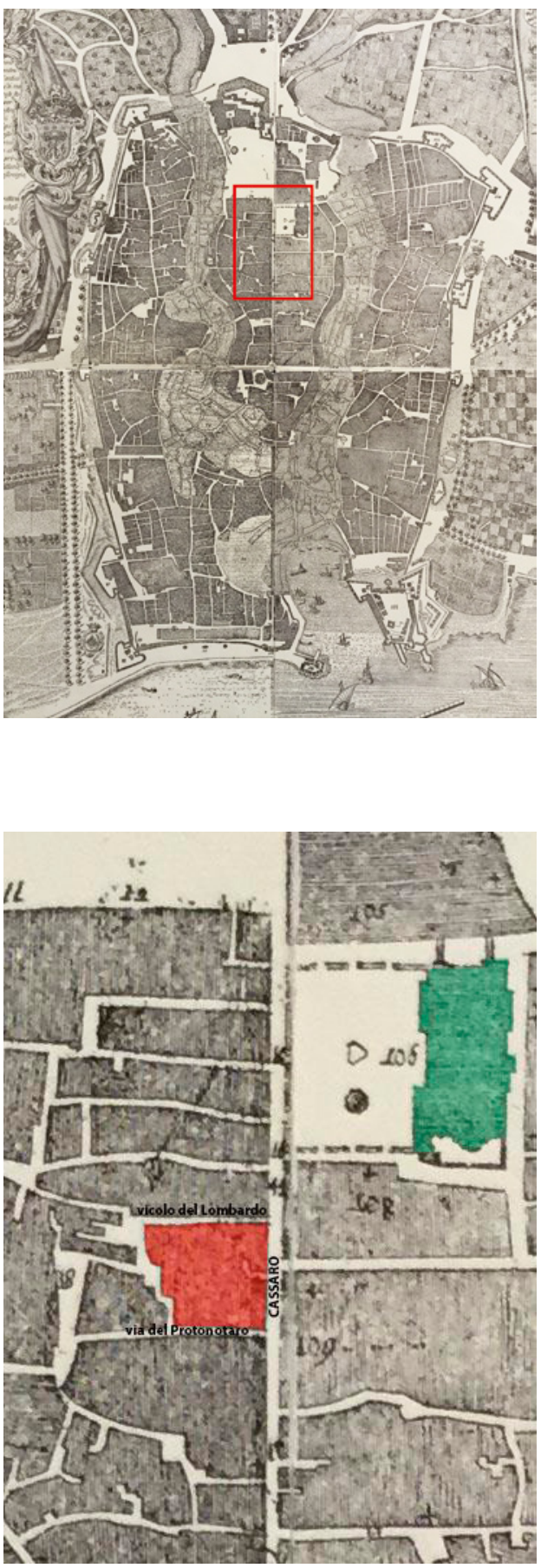

FIGURE 18.1A-B

Francesco Maria Emanuele e Gaetani, Marchese di Villabianca, Pianta geometrica e novella secondo lo stato presente della città di Palermo capitale del Regno di Sicilia coll'antico Palermo giacente in essa e co' sobborghi, molo e campagna, Biblioteca Regionale Palermo, 1777. In the detail: Palazzo Papè is in red, the Cathedral in green 
the sense of a better view and greater visibility - thus implicating both political alliances and enmities. ${ }^{12}$ In Palermo the blocks that flanked the Cassaro were so densely built that any enlargement or raising of palaces could prompt contrasts. Satisfactory agreements for both opponents were possible between parties of equal social weight, as it happened in 1704, when the impeded view of the outdoor events taking place along the Cassaro drove the nuns of the Monastero dell'Oreglione to ask Giuseppe Papè for a passage over the roof of his palace. Yet on most occasions, such conflicts were resolved in favour of the most powerful contender. In 1693, the raising of a room by Ugo Papè was strenuously - albeit ineffectively - opposed by the duke of Rinella, who owned the palace opposite Ugo's, along the vicolo del Lombardo, because the new room reduced the light and the view from one of his windows. ${ }^{13}$ For the same reason, in March 1737 the 'aromataio' (apothecary) Vincenzo Romagnolo tried in vain to stop the building of a part of Giuseppe Papè's new apartment. ${ }^{14}$

The view represented a (visual) encroachment into the outdoor space and, as such, an instrument of political strategy. Participating in outdoor events from windows and balconies meant seeing from above and being seen from below, i.e. being framed in a higher position, physically and socially. The Papè family used the front on the Cassaro mainly for renting, perhaps sensing its profitable potential. The advantages that the view on the Cassaro could offer were obtained, to some extent, from the side front, the via del Protonotaro, where the main entrance of the palace was located. Since the Protonotaro organised the routes of the most important processions, he could easily make them pass along this alley. ${ }^{15}$ Significantly, most anterooms of his main dwelling were located along this side. These rooms were open to visitors and used for banquets during the urban processions passing under their balconies: for example, in July 1714 refreshments were organised on the eve and the day of Saint Rosalia's feast. ${ }^{16}$

Observing with nonchalance from a balcony facing an open space was a usual way to attend outdoor festivities without mixing with the crowd that generally accompanied these events. In 1693, Ignazio De Vio reported that, during the passage of Saint Rosalia's cart along the Cassaro, some spectators attended the event from their own houses as they 'a gran folla aspettavano la comparsa su i balconi, e finestre, che davano in quella strada' ('crowdedly waited for

\footnotetext{
12 Connors J., "Alliance and Enmity in Roman Baroque Urbanism", Römisches Jahrbuch der Bibliotheca Hertziana 25 (1989) 207-294, here 209.

13 The long legal dispute is reported in ASP, Papè, vol. 77.

14 AsP, Papè, vol. 47 , fol. 76 .

15 On the Protonotaro's management of processions, see Salamone, L'archivio privato 27.

16 Asp, Papè, vol. 884, 14 and 15 July 1714.
} 
the appearance [of the cart] on balconies and windows that opened on that road'). ${ }^{17}$ This participation from above was not specifically related to aristocracy since everybody could see processions from the windows of their houses, and, at the same time, aristocrats often walked (or rode) along the streets following the Saints' statues. Yet the aristocratic palaces had the best positions on the principal routes and the view from balconies was also often deemed as more appropriate for highborn people by the most conservative voices. In the description of the running procession of Saints Cosmas and Damian, the Marquise of Villabianca reported:

$[\mathrm{H}]$ o veduto io, Villabianca, persone civili e di qualche riguardo non avere ribrezzo a corrervi di appresso meschiati a plebei, sperando nei Santi ottener fine a' loro mali e perchè, nel corrervi, vi provavano un gran piacere. $^{18}$

I myself, Villabianca, saw civilised people of some respect not disdaining to run behind [the procession] mixed with the plebeians, hoping to obtain from the Saints the end of their pains and because they felt pleasure in running.

The episode and the tone of the comment reveals Villabianca's irritation but also the contradictory attitude of a social rank that wanted to participate in common life and devotion (even if just for a goliardic purpose) but was, despite this, in need of distinction. Analogously, Filippo De Vivo argues that for Venetian patricians walking was considered an abasement of aristocratic etiquette and that the potential contact with people of lower classes provoked anxiety. ${ }^{19}$ Given the height of processional carts, the looking from above arguably happened in Palermo without contradicting the noble arched posture which, according to Georges Vigarello, emphasised the distance and pride of the aristocrats, preventing them from lowering their heads either in a real or metaphorical sense. ${ }^{20}$

\footnotetext{
17 De Vio Ignazio, Li giorni d'oro di Palermo nella trionfale solennità di Santa Rosalia, vergine palermitana celebrata l'anno 1693 (Palermo, Pietro Coppula: 1694) 42.

18 Emanuele e Gaetani Francesco Maria, Processioni di Palermo sacre e profane, ed. A. Mazzè (Palermo: 1989) 59.

19 De Vivo F., "Walking in Sixteenth-Century Venice: Mobilizing the Early Modern City", I Tatti Studies in the Italian Renaissance 19.1 (2016) 133-135.

20 Vigarello G., Storia della bellezza. Il corpo e l'arte di abbellirsi dal Rinascimento ad oggi (Rome: 2007) 84-85.
} 
To sum up, instead of truncating relationships with the outside world out of a desire for intimacy and isolation, architecture seems to arrange them according to temporary agreements affected by political and social causes. However, at this point it seems licit to ask whether this negotiation for space did not also determine the presence of more private places, in the sense of more isolated, at least in the internal arrangement.

The inner articulation of the palace articulated familial relationships in several coexisting apartments. Analogously to Neapolitan palaces, a complex network of relationships shaped the building from the inside, articulating what Gérard Labrot defines as a 'constellation of satellites'.21 In 1713, in addition to Giuseppe's two apartments and some rented houses, the palazzo accommodated Giuseppe's mother, his two brothers, and his mother-in-law, arguably all located in different quarters. Even if the articulation and the interconnection of the apartments cannot now be reconstructed, as the palace is largely ruined, it is still possible to assume that the inside of the palace featured the same crowded density of its neighbourhood and produced the same need for the inhabitants to negotiate their own space.

When Giuseppe Papè succeeded Ugo in 1701, the palace was already equipped with a spacious main dwelling or quarto nobile. ${ }^{22}$ The main dwelling was accessible through a large Sala that gave entrance to the row of anterooms located along via del Protonotaro. Amongst them, a 'Camera di Negotijo' ('room for business') with two tables for the secretary was most probably used for daily institutional duties. ${ }^{23}$ The last anteroom was a large 'Camera di Strato', used for gatherings of every sort. ${ }^{24}$ From here, the dwelling folded along the side that fronted the dormitory of the Monastero dell'Oreglione and a small adjacent piazza. [Fig. 18.2] On this side, the main bedroom, with its bed-alcove and chapel, could hardly boast an intimate atmosphere as it was directly accessible from the Camera di Strato and had to be crossed to reach numerous subsequent backrooms. To sum up, despite its folding around the eastern corner of the palace, the main dwelling had a substantially linear articulation that located the

\footnotetext{
21 Labrot G., Palazzi napoletani. Storie di nobili e cortigiani 1520-1750 (Naples: 1993) 38.

22 Asp, Papè, vol. 125o, fols. 2V-11v.

23 Ibidem, fols. $1 \mathrm{v}-2$.

24 Ibidem, fol. 9. On the use of this room for entertainment, see Amico Giovanni Biagio, L'architetto pratico in cui con facilità si danno le regole per apprendere l'architettura civile, vol. 2 (Palermo: 1997 [1750]) 67.
} 


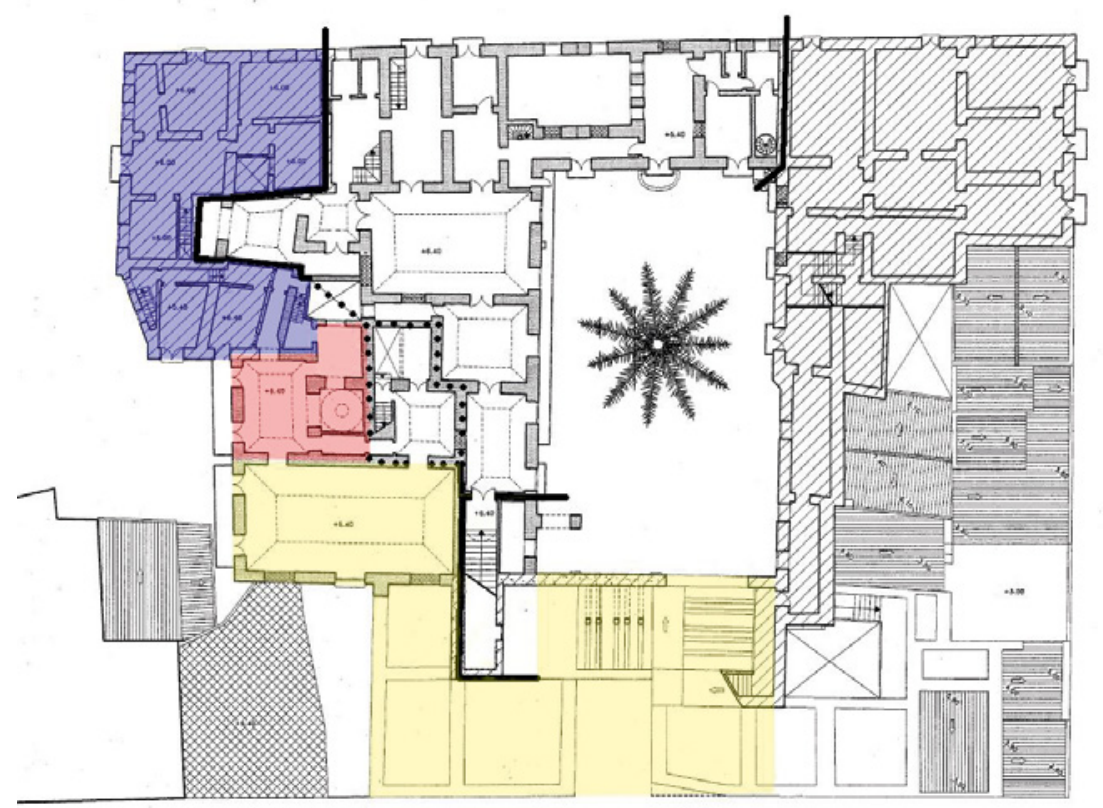

FIGURE 18.2 The piano nobile in 2001. Manipulation of drawing provided by Giuseppe Barresi. The main dwelling. In yellow the anterooms, in light red the bedroom area with the bed alcove and the chapel, in light blue the backrooms

bedroom area between anterooms and backrooms, providing the former with a view of the most frequented alley and pushing the latter towards a quieter neighbourhood. However, this arrangement created a movement that, rather than increasing the inhabitants' privacy, allowed the sphere of business and public relations to insinuate into the domestic. From the first anteroom to the bedroom, each threshold represented for any outsider a change in the grade of intimacy with the host and closeness with his authority. 25

Unlike his father and his son, who dedicated time and money to decorating the family's main dwelling, Giuseppe concentrated his efforts on a new apartment. ${ }^{26}$ This was smaller and effected greater distance from both institutional life and the city by having its entrance on the narrow vicolo del Lombardo and unfolding internally, along the inner courtyard. [Fig. 18.3]

25 Katie Scott argues for both the communicative role of movement along the enfilade of the apartment of Madam Pompadour in Versailles and the diverse importance of the rooms in the row. Scott K., "Framing Ambition: The Interior Politics of Mme de Pompadour", Art History 28.2 (2005) 248-29o, here 26o. 


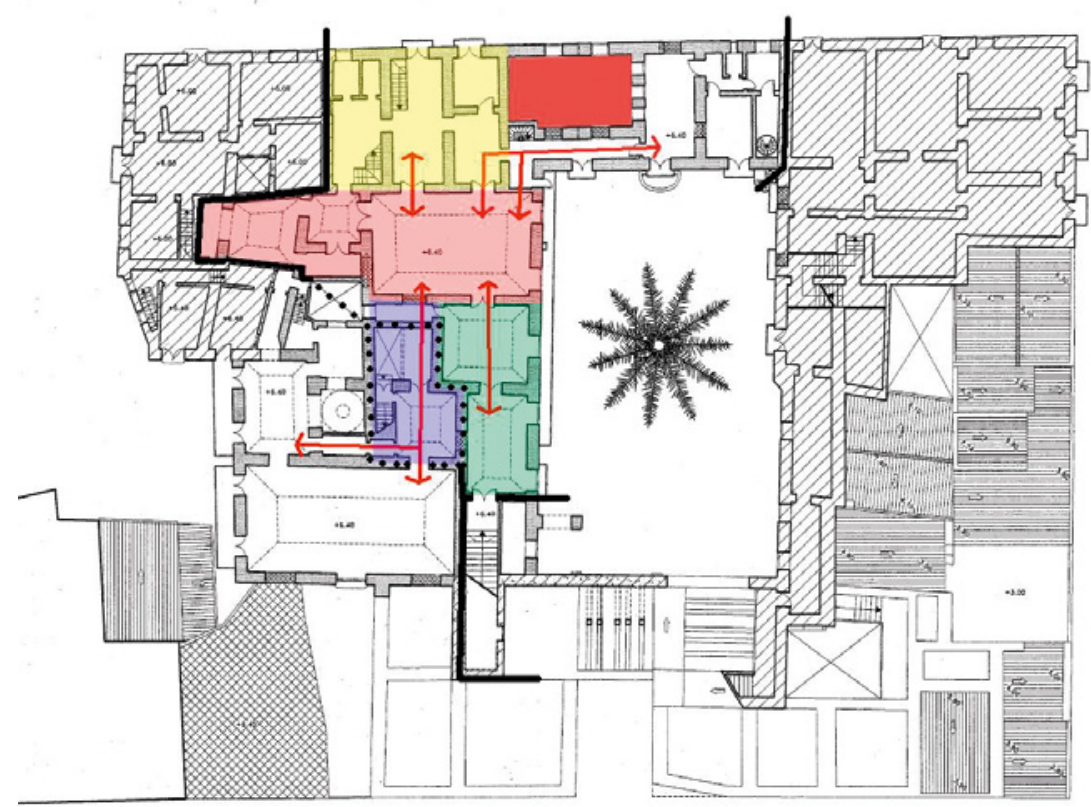

FIGURE 18.3 The piano nobile in 2001. Manipulation of drawing provided by Giuseppe Barresi. The new apartment is highlighted with colours: in yellow the anterooms, in light red the bedroom area, in red the chapel, in light blue the backrooms, in green the library. The red arrows indicate connections present in Giuseppe's time

The 1742 inventory groups Giuseppe's possessions here in two anterooms, a bedroom, a small room, some backrooms, a library, and another room after that. ${ }^{27}$ The bedroom can be identified as the room that, during the works, the architects named 'camerone' for its large size, and a couple of times 'camerone di dormire' (large room for sleeping), that is, the large room at the centre of the apartment. ${ }^{28}$ Due to its central position, the bedroom was linked to the anterooms and the church to the west, the bed-alcove to the south, and the backrooms and the library to the east, whilst it received light and air from the two balconies that opened in the northern wall onto the garden in the courtyard.

It is difficult to say if this sort of radial arrangement around the bedroom resulted more from pre-existing constraints, the architect's project, Giuseppe's

27 Ibidem, fols. $36-59$.

28 Asp, Notai defunti, Magliocco Carlo, vol. 2344, fols. 998v and 999v. The payments for the renovation helped to identify the camerone thanks to the description of the subjacent wall that rests under the flooring. AsP, Papè, vol. 464, fol. $42 \mathrm{v}$. 
own indications, or from a combination of all these factors. Whatever the case, this articulation had the striking consequence that it gave prominence to the bedroom as the core of the apartment, more than in the main dwelling. Its importance emerges as a consequence of being the main dwelling place of the prince. Opening onto the bedroom and opposite to the courtyard, the vaulted alcove offered rest to Giuseppe while, in front of it, the fireplace warmed both his body and the surrounding environment. Special structural attention was devoted to the bedroom as it was reinforced by new masonry walls and four 'catene' (iron bars), which were located along its walls. ${ }^{29}$ Furthermore, the room was equipped with two trapdoors, hidden in the flooring and leading to two different rooms on the lower floor, most probably to allow escape in case of emergency. ${ }^{30}$

The apartment was probably for Giuseppe's almost exclusive use and can, therefore, be considered a personal space more than the other parts of the palace. Unlike the possessions inventoried in the main dwelling, the objects inside the new apartment supported the practicalities of his daily life. ${ }^{31}$ A gendered (male) characterisation reflecting Giuseppe's role as the head of the household can also be sustained. ${ }^{32}$ This does not necessarily mean, however, that the prince always dwelt in these spaces neglecting his bedroom in the main dwelling nor that he dwelt here alone. For instance, the backrooms were used by female servants. ${ }^{33}$ Furthermore, the presence of two crucifixes of ivory and tortoiseshell on each side of the bed might suggest both a search for symmetry and the (occasional?) presence of both spouses in the bed. ${ }^{34}$

The close relationships that Giuseppe had with the other family members were not in contradiction to the realisation of his new apartment nor to the

29 ASP, Notai defunti, Not. Magliocco Carlo, vol. 2345, fols. 54-56v, 66v.

$30 \quad$ Ibidem, fols. 66 and $293 \mathrm{v}$.

31 It is worth noting that Giuseppe's inventory names the main dwelling as the 'casa di propria abitazione' ('house where he lives'). AsP, Papè, vol. 1250, fol. 1. The document seems to suggest that the 'new apartment flanking the church of San Tomaso di Cantoaria' was a sort of additional space for him. However, Giuseppe's clothes were stored in its backrooms. Ibidem, fol. 38 .

32 An allusion to Giuseppe's role as head of the household arises from the presence of six arrases depicting the story of Samson hanging in his bedroom. Ibidem, fols. $29 \mathrm{v}$ and 37 . Depictions of heroic biblical characters were often used to delineate the role of the universal heir, but the story of Samson, who was deprived of the source of his strength (his hair) by Delilah while he slept, could also alert the heir to the (female) danger at the moment when he was weakest.

33 Ibidem, fols. $38 \mathrm{v}-39$. Beds, linen, and other things are listed as 'per le donne' ('for women') or 'per serv[izi]o di donne di casa' ('for the use of women of the house').

Ibidem, fol. 37 . 
search for room that this realisation seems to imply. Rather, this interior space articulated these relationships by allowing different grades of participation and isolation through the closing and opening of doors placed between the new apartment and the main dwelling. Since the two houses were wedged into each other, the backrooms of the new apartment could be entered from the bedroom of the main dwelling as well as from its Camera di Strato. This articulation allowed the prince to take refuge in his quarters during a social event or from the bedroom he shared with his wife. Of course, it also allowed Giuseppe to return to his daily duties as the head of the household and Master Notary of the Kingdom. Analogous examples of this versatility emerge from Sandra Cavallo's investigation of the inner articulation of baroque palaces in Rome. ${ }^{35}$ Cavallo highlights how fluid arrangements, temporary adjustments, and movements of the family members from one apartment to another resisted permanent divisions between male and female spaces and prevented the formation of a stable demarcation between private and public spheres. ${ }^{36}$

As to gender relationships, Giuseppe was surrounded by strong female members of his family, such as his mother Camilla Montaperto (?-1716), who oversaw everything in the palace until her death, his wife Caetana Ballis (m. 1710-1770), who gave him an heir and a conspicuous patrimony, and Anna Valdina (1634-1702), who bequeathed her possessions to Giuseppe. ${ }^{37}$ In this respect, the origin of some of the furnishings in Giuseppe's bedroom is particularly significant: the bed in the alcove, for instance, was made of precious embroidered fabrics of different colours interwoven with some damasks donated by his wife and others coming from the inheritance of Anna Valdina. ${ }^{38}$ Female support was deemed to be part of the structure sustaining - literally and symbolically - the body and role of the head.

In conclusion, despite the greater isolation that the new apartment produced in comparison with the main dwelling, it did not seclude its primary occupant within untraversable boundaries but connected him to people,

35 Cavallo argues that, despite the increasing specialisation of domestic rooms emerging from early modern literature, the practical daily use of inner space remained variable. Cavallo S., "Space, Privacy, and Gender in the Roman Baroque Palace", Historische Anthropologie 26.3 (2018) 287-307, here 290-291.

36 Ibidem, 294.

37 On Camilla's domestic management, see ASP, Papè, vol. 885. After struggling for ages to abandon her position as a nun, Anna Valdina managed to leave the convent thanks to the help of Ugo Papè, in whose house she lived for the last three years of her life.

Ibidem, fol. $36 \mathrm{v}$. 
places, and roles. This coexistence of opening and closing aspects becomes more significant in the connection between the apartment and the church of San Tomaso.

From the outset, the works on the new apartment involved the adjacent church of San Tomaso, a sign that the apartment was already considered an integral part of the building. This peculiar bond represented the last phase of a gradual process of appropriation that the church underwent long before the settlement of the Papè family. The fact that in seventeenth-century documents the name of San Tomaso is often followed by the appellation 'chiesa seu cappella' ('either church or chapel') suggests an existing tradition of dual use. ${ }^{39}$ Constructed soon after 1173 by a Norman queen, the church had undergone various modifications since $1549 .^{40}$ These modifications increasingly provided the subsequent inhabitants of the adjacent building with the possibility of attending services from a room of their house with a window open onto the nave. ${ }^{41}$ This artifice de facto connected the domestic and the religious spheres.

Giuseppe's renovation went further. Against all previous prescriptions forbidding a direct connection between the house and the church, a hidden wooden spiral staircase connected the new apartment with the church nave. ${ }^{42}$ Each upper landing of these stairs corresponded to a small corridor or passetto - located between the nave and the palace courtyard. [Fig. 18.4]

39 Unlike the conjunctions aut, which opposes two terms, and vel, which proposes a choice between two terms, seu or sive (often repeated as seu [...] seu [...]) in Latin indicates a plurality of conditions, even coinciding.

40 In 1522, this small church came under the patronage and care of the abbess of the Martorana monastery, who granted to various beneficiaries a right (beneficio semplice) over the church. They, in turn, were obliged to pay an annuity, celebrate religious services, and support a referent. AsP, Papè, vol. 54 .

41 Biblioteca Comunale di Palermo (hereafter: BCP), Ms. Qq E 9. Mongitore Antonino, Le Confraternite, le chiese di nazioni, di artisti e di professioni, le Unioni, le Congregazioni e le Chiese particolari, fols. $454 \mathrm{v}-456$.

42 Beneficiaries running the church could not remove the old depiction of Saint Thomas or create stairs connecting their house to the church. AsP, Papè, vol. 54, index. The staircase was called 'secreta' (secret), because it was understandably hidden from the sight of the faithful. AsP, Papè, vol. 464, fol. 83v. 


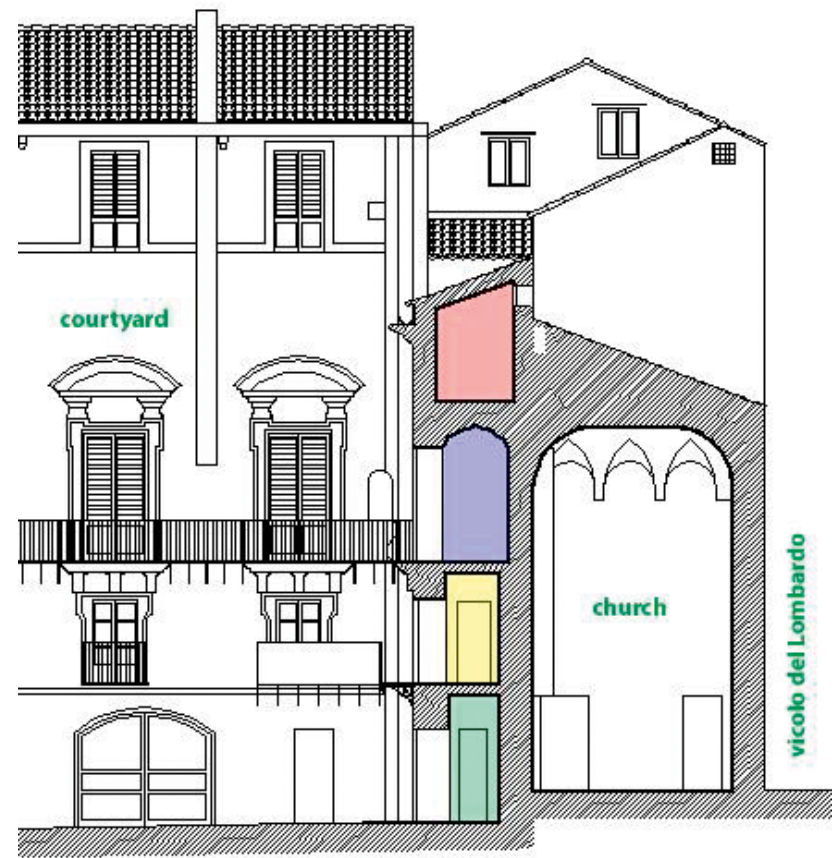

FIGURE 18.4 Overlapping corridors (section). Manipulation of drawing provided by Giuseppe Barresi. The nuns' corridor is in red, the passage in connection to the courtyard is in green, the passage leading to the litterino delli musici in yellow, and the prince's passetto in blue

The first corridor, without any inside view, led to a lower space for musicians (litterino delli musici), which had three arched openings onto the nave and was equipped with an organ. Above it, the second corridor connected the new apartment to a higher litterino, equipped with three other arched windows onto the nave [Figs. 18.5-18.6] and accommodating the family members while they attended the mass. ${ }^{43} \mathrm{An}$ inside view of the church was possible also from the second corridor itself, which had, on one side, a large window onto the palace courtyard, and, on the other, two iron-grating windows onto the church

43 The word litterino - also letterino or lettorino - in seventeenth and eighteenth-century documents indicates an inner balcony or a room with a view from above into a larger space (usually a church); it was often a protruding space planned to accommodate musicians or a choir. Tedesco A., "Musica, architettura e arti figurative nella Palermo di Giacomo Amato", in de Cavi S. (ed.), Giacomo Amato. I disegni di Palazzo Abatellis. Architettura, arredi e decorazione nella Sicilia Barocca (Rome: 2017) 114. 


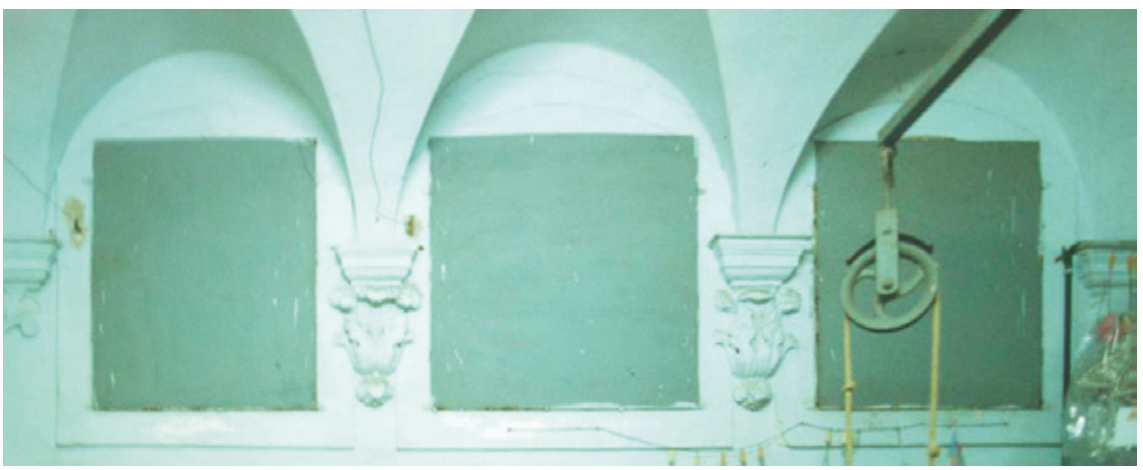

FIGURE 18.5 The three arched windows of the two superimposed litterini from the church. Photograph by Giuseppe Barresi (ca. 1999)

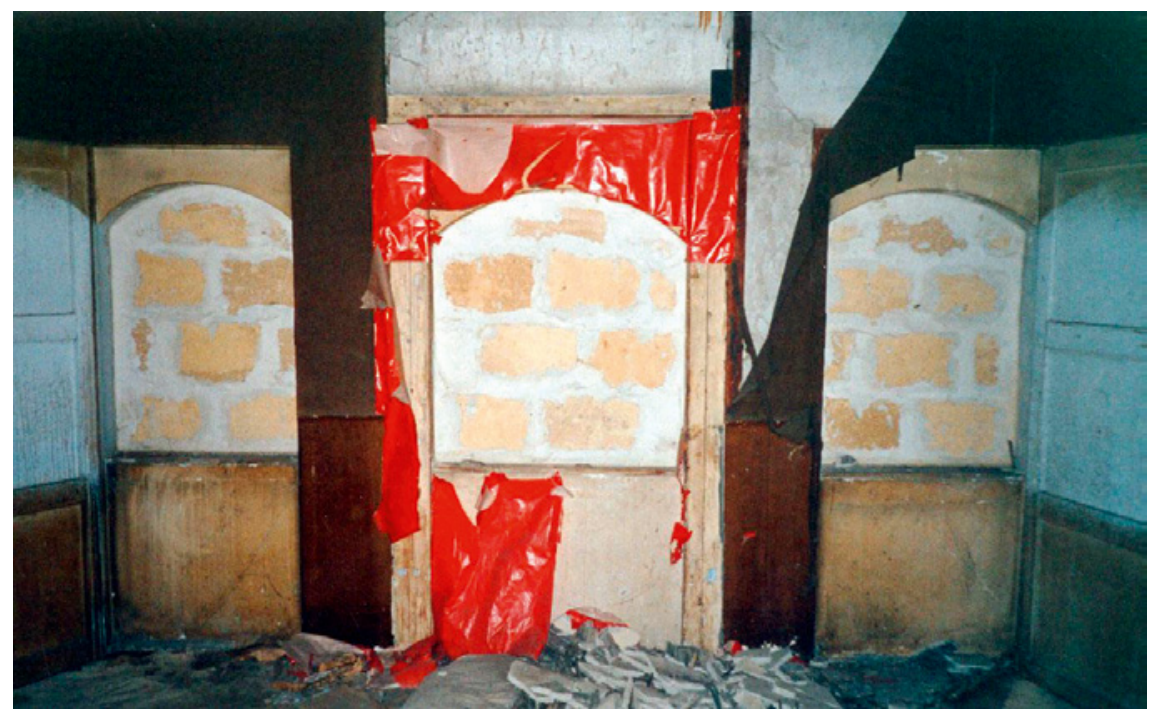

FIGURE 18.6 The three arched windows of the litterino on the piano nobile from inside the new apartment. Photograph by Giuseppe Barresi (ca. 1999)

nave. ${ }^{44}$ [Fig. 18.7] While the litterino, located in front of the altar but behind

44 The word passetto recalls the Spanish pasadizos, which were often used in the same period to extend the aristocratic dwelling above urban streets, mostly, but not exclusively, to reach a church and attend its services. Tovar Martín V., "El pasadizo, forma arquitectónica encubierta en el Madrid de los siglos XVII y XVIII", Villa de Madrid 24 (1986) 38. Although the Spanish version already had a long tradition and a more extensive use, its influence on similar examples in Southern Italy cannot be excluded. For Neapolitan examples, see Labrot, Palazzi napoletani 91. 


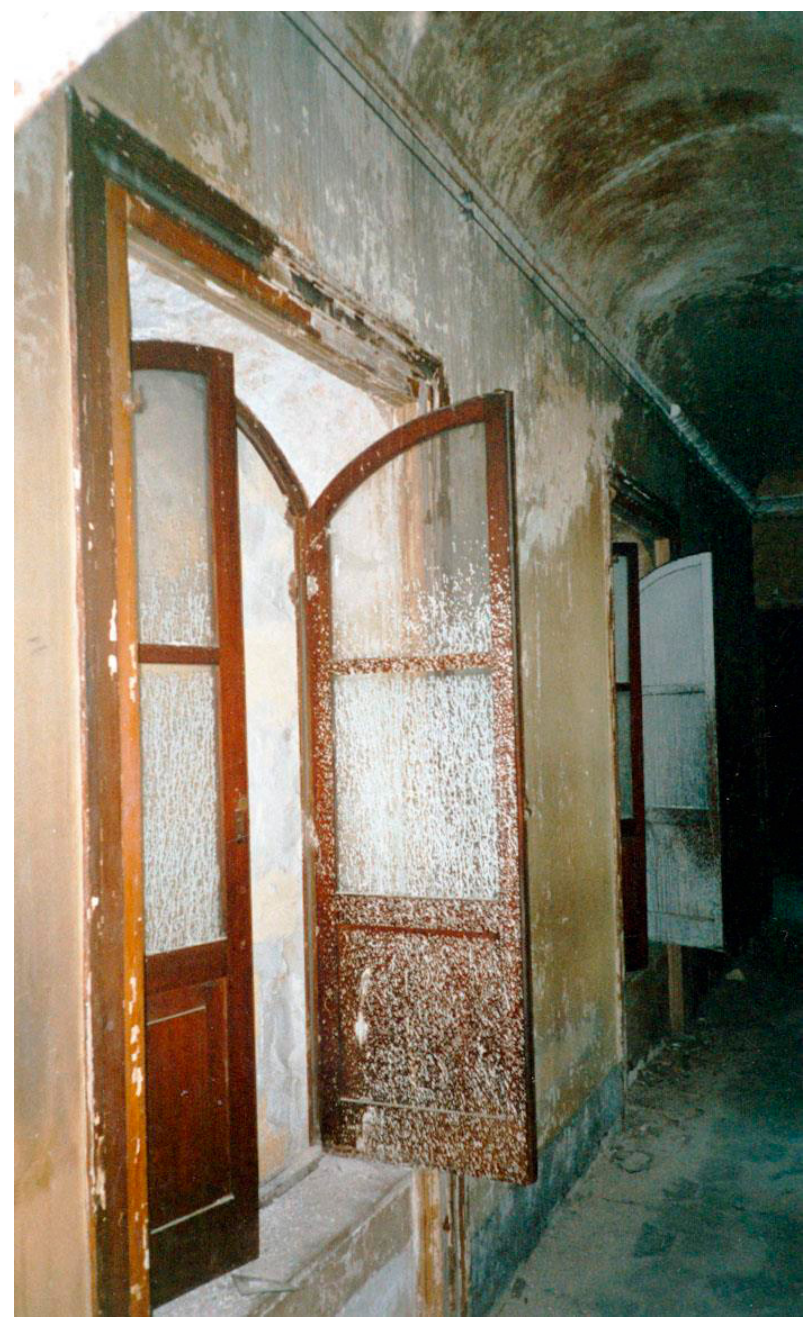

FIGURE 18.7 The windows of the passetto onto the nave.

Photograph by Giuseppe Barresi (ca. 1999)

the congregation, facilitated hidden participation, the passetto, with its two windows along the nave, deliberately made the family visible to the people gathered there. The two windows were equipped not with grilles but with panels, which, because of their height from the nave floor, were arguably opened and closed by the people of the house. ${ }^{45}$ The opposite window, opening onto the courtyard, illuminated the passetto from the east and its occupants from

45 ASP, Papè, vol. 464 , fols. $84 \mathrm{v}$ and $95 \mathrm{v}$. 
behind. In this way, the nobles could make an unexpected and surprising occasional appearance from above, and the luminous figure of the Protonotaro could itself be associated with a powerful devotional image, in a way similar to his appearance on the balconies along via del Protonotaro during processions, but here enhanced by the location inside the church. ${ }^{46}$

Scholars working on domestic devotion in early modern Italy have often considered the domestic chapel as one of the most withdrawn places of the house, suitable for prayer and meditation. ${ }^{47}$ Due to the limited intimacy of the bedroom in the main dwelling, this interpretation hardly suits the small chapel flanking the bed alcove there, but even less does it describe the chapel of the new apartment that was de facto a church open to the neighbourhood. Instead, it must be considered that views and connections were intended, primarily, for the benefit of the main user of the new apartment, namely the Protonotaro. From the core of the apartment Giuseppe could either reach a first-floor elitist position - either in the corridor or in the litterino - whence he could attend religious celebrations or go down into the nave and participate in the services together with the congregation. ${ }^{48}$ Additionally, more than one priest's salary was paid to have services celebrated in both the church of San Tomaso and the chapel of the main dwelling. ${ }^{49}$ Therefore, the family might be divided between the two devotional spaces for ordinary services and reunited for special celebrations in the church. ${ }^{50}$ All this suggests that, although inserted

46 It has been argued that the veiling and unveiling of devotional images was a way to preserve their protective power, both in church and at home. Cooper D., "Devotion", in Ajmar-Wollheim M. - Dennis F. (eds.), At Home in Renaissance Italy (London: 2006) 192. Brundin A. - Howard D. - Laven M., The Sacred Home in Renaissance Italy (Oxford: 2018) 87; Howard D., "Family Life", in Corry M. - Howard D. - Laven M. (eds.), Madonnas and Miracles: The Holy Home in Renaissance Italy (Cambridge: 2017) 9.

48 To shorten the distance between Giuseppe's bedroom and the church a new door between the passetto and the bedroom was opened. Asp, Notai defunti, Not. Magliocco Carlo, vol. 2341, fols. 993r, 993v, 999v, and 10oo. The opening of this door so close to the extreme edge of the wall was followed by a reinforcement of the masonry at the corner. Ibidem, fol. 994v.

49 The family's registers report numerous payments to priests for religious services, but they are frequently divided into masses celebrated 'nella cappella della casa delli Sig[no]ri $\mathrm{n}$ [ost]ri' ('in the chapel of the house of our Lords') and 'nella chiesa di S. Tomaso' ('in the church of San Tomaso'). ASP, Papè, vol. 819, on 30 November 1707.

50 Silvio Antoniano suggested a separate use, for men and women, of the same chapel. Antoniano Silvio, Dell'educazione cristiana e politica de' figliuoli: libri tre (Florence, Tipografia della Casa di Correzione: $185^{2}$ [1583]) 316. Laura Malo Barranco hypothesises that Antoniano's suggestion could be easily converted into the use of two different chapels when the aristocratic house was equipped with them. Malo Barranco L., "Los espacios 
in an apartment more distant from institutional life, the church/chapel of San Tomaso had a more political role than the other chapel.

It is worth noticing that the renovation coincided with a difficult period for the family. In 1708, the king rejected Giuseppe's request for an extension of the Protonotaro's office to two subsequent generations of the family as he disagreed with the sum that Giuseppe proposed to pay. ${ }^{51}$ The rejection put the entire family in an uncertain situation, since the position not only provided Giuseppe with connections, power, and prestige within Palermitan society, but also confirmed his role as a vehicle of transmission of the family's achievements incremented by his individual contribution..$^{52}$ The dispute lasted until the entry of Austrians as new rulers of Sicily (1720), who offered the office to another nobleman. ${ }^{53}$ This occurred also because the new king was mistakenly informed about Giuseppe's death. The misunderstanding was probably caused by the fact that Giuseppe was suffering from pulmonary tuberculosis at that time. ${ }^{54}$ Giuseppe dealt with this difficult period of his life with the support of all his family. He was strongly supported by his brother Domenico, who frequently substituted him in the main tasks of the Protonotaro. ${ }^{55}$ The fact that the substitution occurred at crucial moments like the official visit of the King of Savoy to the Parliament (4 March 1714) or for prestigious roles like the Governor of the Compagnia dei Bianchi suggests the strength of the

de religiosidad y la devoción femenina en la nobleza moderna. El ejemplo de los linajes Aranda e Híjar", Cuadernos Historia Moderna 42.1 (2017) 175-193, here 182.

51 Salamone, L'archivio privato $22-23$.

$5^{2}$ Giuseppe rearranged most of the documentation regarding the family's assets between 1724 and 1729, that is, between the period of his illness (1720s) and the reconfirmation of the office of Protonotaro (1731). This fact can be read as an attempt to reaffirm his political role through the memory of familial achievements.

53 Asp, Papè, vol. 395, fols. 204-204v.

54 Ibidem, fol. 204v. It has been written that Giuseppe eventually accepted the king's price as he was in a 'pericoloso stato di salute per il sputo di sangue' ('dangerous state of health for the spitting of blood').

55 At the joint sessions of the three parts of the Sicilian Parliament, Domenico replaced his brother on 4 March 1714, 25 October 1720, and 7 July 1732. However, Giuseppe was present on 13 November 1723, 13 August 1725, and 26 June 1728. The two brothers were so interchangeable that the report of the session held on 20 April 1734 cites, by mistake, both present in the same capacity. Mongitore Giuseppe Antonino, Parlamentigenerali del Regno di Sicilia dall'anno 1446. fino al 1748. con le memorie istoriche dell'antico e moderno uso del Parlamento appresso varie Nazioni, ed in particolare della sua origine in Sicilia, e del modo di celebrarsi, vol. 2 (Palermo, Nella Nuova Stamperia de' ss. Apostoli in Piazza Vigliena presso Pietro Bentivenga: 1749) 130, 140, 169, 179, 188, 200, and 214. 
bond of trust between the two brothers. ${ }^{56}$ However, this familial strategy was severely tested in 1716, when Domenico himself had some health problems and Giuseppe's mother suddenly died. ${ }^{57}$ It is impossible to know the reasons for all these medical troubles, but they make comprehensible the fact that the family turned to both medicine and worship when Giuseppe's wife gave birth to their son in $1715 .{ }^{58}$

These facts may have increased the family's need for political visibility and consequent reaffirmation that architecture could provide. The church brought to the family a significant bond with the Norman past (1072-1198), idealised as a period of splendour and reborn Christianity for Palermo after the Islamic rule (904-1072). The church also made visible the family's direct management of the sacred analogously to the chapel of the Holy Shroud for the House of Savoy. As Belton Scott argues, in Turin a proscenium was built by Guarino Guarini between the shrine and the cathedral nave and in connection to the piano nobile of the duke's palace. ${ }^{59}$ The aim was both to show the relic to pilgrims and worshippers and to indicate its ownership by the House of Savoy, thus increasing the dukes' political prestige. To make this bond tighter, the ostensions of the Shroud coincided with significant moments in the history of the family and were extended to the adjacent open spaces through processions during which the members of the family carried the relic personally. It is unknown in what ways the heads of the Papè household were involved in the devotional rites to Saint Thomas, but they certainly had the responsibility to celebrate Mass in honour of the saint. Furthermore, although the inventory of Giuseppe's possessions lists all the relics in the sacristy, it also reports 'l'autentiche' (the certificates of authenticity) to be stored in 'the archive of the most illustrious prince of Valdina'.60 This location cannot be deemed a temporary solution to a lack of space (like other pieces of church furniture that were stored in the mezzanines). Rather, it seems that the Protonotaro was guarantor of the relics' authenticity.

56 Despite being chosen as Governor of the Company in 1714, Giuseppe was replaced by Domenico from April 1715 to January 1736. Emanuele e Gaetani, Della Sicilia nobile, vol. 2, 153 .

57 Domenico's medical visits increased between May and June 1716. AsP, Papè, vol. 885 .

$5^{8}$ For a safe delivery, whilst the doctor used bloodletting for the mother-to-be, the family paid for prayers to Saint Margaret, protectress of pregnant women. ASP, Papè, vol. 885, 15 January and 26 June 1715 .

59 Beldon Scott J., "Seeing the Shroud: Guarini's Reliquary Chapel in Turin and the Ostension of a Dynastic Relic", The Art Bulletin 77.4 (1995) 6o9-637, here 636-637.

6o AsP, Papè, vol. 1250, fols. 28-28v. 
All this blurs the borders between secular and religious spheres and raises questions concerning the close connection between Catholic post-tridentine devotion and political strategy.

\section{Aristocratic Distinction and Catholic Sharing}

The political use of the holy did not exclude a sincere devotion but was embodied within it. Understandable anxieties for the future of the family, related to social position and health, may have driven Giuseppe's mind to religion in search of assistance and salvation. An idea of the efficacy attributed to devotion seeps from the lines with which, years later, the Marquise of Villabianca interpreted the opinion of Giuseppe's son:

E, però, oh!, Dio volesse che tutte le altre famiglie di grandi con santo ora consiglio seguissero il fatto della Papè, imitandone la pietà, chè certamente in tal modo si farebbe lungi da esse e dal Papè la decadenza e la pauperie si bandirebbe, che or dapertutto, per la nostra commune disgrazia, va a deplorarsi. ${ }^{61}$

And yet, oh! May with God's will all the other great families now with holy advice follow the agency of the Papè [family], imitating their piety, that certainly in this way decadence would be distanced from them and from the Papè [family], and the poverty, which now, for our common misfortune, is everywhere deplored, would be banished.

What emerges between the lines is the conviction that devotion guarantees divine protection for the family against decadence and poverty and that this protection results in wealth and prosperity for the household. This process of salvation, however, was considered neither individual nor familial. The aristocratic search for redemption was with and within the city, even if it had its own routes and modes of access, partly brought about by architecture. It was a matter of tactfully aligning the evangelical duty of participation - ensuing from the Council of Trent (1545-1563) - with the need of aristocratic distinction, and of establishing a temporary balance between the collective aspects of devotion and the spiritual life of the person and their family. In the examined case, this objective was achieved through tactical positioning and visual supremacy, that is, through the same strategies that were used within the broader competitive

61 вСР, Ms. Qq E 88, n.3. Emanuele e Gaetani, Delle antiche chiese e de' privati oratori, fol. 14. 
context of the city. ${ }^{62}$ The aristocratic ambition for visual control was practised over a church nave and its congregation and implemented by measures that significantly orchestrated the appearance of the nobles to stress their presumed greater closeness to God.

The participation of the Papè family in processions should be read in this sense. By organising processions, the Protonotaro enabled distant saints to act in the city and for the city's salvation and, thereby, acquired authority from his mediating role. At the same time, the Papè family benefitted from the same process of salvation as the city but from an elitist position. It would be an understatement, however, to claim that there is in this distance a dualistic opposition between public and private space, in the sense of an undifferentiated space for everyone and an exclusive space for the noble family. The issue was more complicated than this. During these events, participants appropriated and somehow privatised the urban space by dividing it and using it according to the dynamics of social hierarchy. For instance, during the 1610 Corpus Domini procession, there was unrest due to the fact that the manifold religious associations acting in the city (companies, confraternities, and congregations) started fighting for the best position in the cortège. ${ }^{63}$ In turn, the anterooms of palaces were open also to people outside the family and the parties taking place there were used for political manoeuvres. In 1656 and 166o, the prince of Cattolica, whose palace was in front of one of the principal processional stops, i.e. the church of San Francesco, had the pleasure of hosting the viceroy himself to attend the event 'dalli finestroni' ('from the big windows') of his palace. ${ }^{64}$ The mention of the event in an urban chronicle suggests the extent of the political benefit that this invitation guaranteed to the host.

\section{5}

\section{Conclusion}

The Papè palace produced interrelated spaces and multiple paths, thus articulating the roles of the family members and their gender relationships and organising the interactions between the family and the city. The palace location, its inner arrangement, and its bond with the church of San Tomaso

\footnotetext{
62 For another significant example in Palermo see Viola V., "Excess without Display. The Chapel of Palazzo Scordia in Palermo (1683-1720)", in Viola V. - La Delfa R. - Scordato C. (eds.), La Sovrabbondanza nel Barocco (Leonforte: 2019) 286-309.

63 Scalisi L., Il controllo del sacro. Poteri ed istituzioni concorrenti nella Palermo del Cinque e Seicento (Rome: 2004) 25 .

64 Mazzarese Fardella E. - Fatta Del Bosco L. - Barile Piaggia C. (eds.), Ceremoniale de' Signori Vicerè (Palermo: 1976) 238, 260.
} 
politically enhanced the family's involvement in the city and its mediating role in the management of the holy. The new apartment, i.e. Giuseppe Papè's own quarters, arranged different sites around the bedroom, thus placing the prince at the centre, but simultaneously directing him towards a range of possible rooms and manifold modes of occupation. Every site participated in the production of the different aspects of Giuseppe's persona, as he was the accomplished man studying in the library, the guiding pater familias who took care of his family, the Protonotaro with his responsibilities, and the religious devotee. Instead of enhancing Giuseppe's seclusion, architecture generated for him different degrees of participation in the family's and city's events according to how and when the prince of Valdina occupied its spaces. In this sense, the new apartment was both the product of Giuseppe's use of space and the pre-existing condition that determined this use.

In conclusion, this chapter reveals residential architecture more prone to organise connections and to regulate the crossing of borders and the sharing of spaces than to clearly divide areas. In comparison with the main dwelling, the new apartment was more distant from the institutional life and more personalised, that is, built for and around Giuseppe. However, it also created familial and social connections for its occupant and enhanced his political role, especially through its link with the church of San Tomaso. In this context, the search for personal isolation appears secondary to political priorities. The boundaries of the architectural space were the result of hierarchical conventions, continuous negotiations, and temporary agreements, which were affected by issues of rank and gender but rather heedless of aristocrats' privacy.

\section{Selected Bibliography}

Ajmar-Wollheim M. - Dennis F. (eds.), At Home in Renaissance Italy (London: 2006).

Benigno F., Lisola dei viceré. Potere e conflitto nella Sicilia Spagnola (sec. XVI-XVIII) (Palermo: 2017).

Brundin A. - Howard D. - Laven M., The Sacred Home in Renaissance Italy (Oxford: 2018).

Campbell E.J. - Miller S.R. - Consavari E.C. (eds.), The Early Modern Italian Domestic Interior 1400-1700: Objects, Spaces, Domesticities (Farnham: 2013).

Cavallo S., "Space, Privacy, and Gender in the Roman Baroque Palace", Historische Anthropologie 26.3 (2018) 287-307.

Connors J., "Alliance and Enmity in Roman Baroque Urbanism", Römisches Jahrbuch der Bibliotheca Hertziana 25 (1989) 207-294. 
Corry M. - Howard D. - Laven M. (eds.), Madonnas and Miracles: The Holy Home in Renaissance Italy (Cambridge: 2017).

Corry M. - Faini M. - Meneghin A. (eds.), Domestic Devotions in Early Modern Italy (Leiden: 2018).

Franco Rubio G.A. (ed.), La vida de cada día. Rituales, costumbres y rutinas cotidianas en la España moderna (Madrid: 2012).

Hamling T. - Richardson C., A Day at Home in Early Modern England: Material Culture and Domestic Life, 1500-1700 (New Haven - London: 2017).

Hills H. (ed.), Rethinking the Baroque (Farnham: 2013).

Labrot G., Palazzi napoletani. Storie di nobili e cortigiani 1520-1750 (Naples: 1993).

Maurer M.F., Gender, Space and Experience at the Renaissance Court: Performance and Practice at the Palazzo Te (Amsterdam: 2019).

McIver K.A. (ed.), Wives, Widows, Mistresses, and Nuns in Early Modern Italy: Making the Invisible Visible through Art and Patronage (Farnham: 2011).

McKeon M., The Secret History of Domesticity: Public, Private, and the Division of Knowledge (Baltimore, MD: 2009).

Orlin L.C., Locating Privacy in Tudor London (New York: 2009).

Sarti R., Vita di casa. Abitare, mangiare, vestire nell'Europa moderna (Bari: 2003).

Scalisi L., Il controllo del sacro. Poteri ed istituzioni concorrenti nella Palermo del Cinque e Seicento (Rome: 2004).

Waddy P., Seventeenth-Century Roman Palaces: Use and the Art of the Plan (New YorkCambridge: 1990). 